\title{
The actualization of Local Wisdom Values in Strengthening Student's Character
}

\author{
Rusli Yusuf ${ }^{1}$, Sanusi $^{2}$, Maimun ${ }^{3}$ \\ ${ }^{1}$ Associate Professor in Department of Pancasila and civic education at Faculty of Education \\ and Teacher Training, The University of Syiah Kuala \\ ${ }^{2}$ Lecturer in Department of Pancasila and civic education at Faculty of Education and Teacher \\ Training, The University of Syiah Kuala \\ ${ }^{3}$ Lecturer in Department of Pancasila and civic education at Faculty of Education and Teacher \\ Training, The University of Syiah Kuala
}

\{rusliyusuft@unsyiah.ac.id\}

\begin{abstract}
Actualization on character education is an essential domain to be expanded in all education level, which aims to create an integral character of an individual. There should be a serious attempt to look on the challenge and opportunity in developing character education at the formal education board. This research focuses on the actualization of local wisdom values in strengthening student's character of Syiah Kuala University. It aims to: identify local wisdom values to be developed to students of Syiah Kuala University. Furthermore, the research aims to identify challenges and opportunities to perform local wisdom values in strengthening student's character at Syiah Kuala University. Qualitative research design is conducted by using descriptive analysis and comprehensive interview as a medium to collect data. Research subjects are 45 people from structural leaders and experts surround Syiah Kuala University. The research proves that there are three sources of value influencing local wisdom and formulated as basic in strengthening the character of the student at Syiah Kuala University, that is Islamic value, nationality value, and Acehnese cultural values. Research findings, then, reveal that strategy to implement local wisdom values in Syiah Kuala University can be performed by the curricular program, extracurricular and co-curricular. In another part, the research also finds that actualization models of character education in Syiah Kuala University are conducted by three models: a) integrative model, (b) compliment model, and (c) discrete model.
\end{abstract}

Keywords: Character, Local Wisdom Values

\section{Introduction}

Geographically, Indonesia is an archipelagic large country. Indonesia has positively supported and consisted of some factual having strategic geopolitical position, natural resources and biodiversity, socio-cultural plurality, and a large population. People of Indonesia, then, have enormous opportunities to develop, equitable, prosperous and dignified. In quantity, Indonesia is a country with the fourth rank of the largest population in the world, but in term of quality, Indonesia is a country with "worst" rank in all aspects. "Worst" is caused by the inefficiency of the education process. A nation will be more left behind when the education sector is not managed as well, although it is a nation that fully loaded with natural resources, the nation remains underdeveloped.

The process of education is a key sector that should be constantly improved to pursue changing demands of the age. It has to be admitted that modern countries with advance 
education (such as Japan, America, and some European) have been able to exploit potential energy resources possessed by other countries. Moreover, modern countries have also successfully conquered the world economy line. For that reason, developing country such as Indonesia was subject to the rules set by the superpowers. This situation arises and caused by degenerated education in Indonesia, either in quality or quantity.

In relation to education, it is not only concern on the ability of knowledge transfer, or power output of technology, but also concern more complex on the transfer value. History has proven that dignity and noble level of a nation depends on its character. Philosophers and leaders prioritize on education values/character than others. No matter how to advance a nation in science and technology, it often brings to destruction, which harms people. Character education in Islam is based on the faith of One God, as "Creator" and "Source" of all goodness and truth.

Characteristic dimension in Islam is exposed in relation to goodness and avoiding His prohibitions. In placing such positive and negative issue, human build a good thinking, peaceful soul, strong personality, and a healthy body. Character in the Islamic perspective is a combination of faith in God, religious ritual (spiritual activity), and social behavior in all aspects of human life.

If we tracing back on the history of Aceh, nearly all writings that we will find regarding culture and customs are "defaulted" into Acehnese value. It is implemented in all life aspect by Acehnese in reference to Islamic value. Since Acehnese consists of people with the Moslem majority who committed to the teachings of religion. For Acehnese, religious knowledge is a must [1]. Morality is one of the most emphasized principles of Islam. It is proven that Allah has sent Prophet Muhammad to the world to edify human morals. Without morals and morality, knowledge will be disrespected. It is then leading to technology "deviation", which can harm and even threatening the human race. We have to admit that, most of the time, education in Indonesia is oriented only to knowledge, whereas education value is abandoned. While national regulation for education system Sisdiknas Regulation year (2003), chapter II, article 3, stated that:

"National education serves to develop the ability and figuring out character and civilization of nation in order to educate human life, aimed to expand potential learners into believers to God the Almighty, has good behavior, health, educated, skillful, creative, independent, become a democratic citizen and responsible."

It is clear that education is not merely the knowledge transfer process, but also as a medium to build personality, mindset, psychology, and pattern of behavior. Therefore, urgent awareness about developing character education takes place in all formal institutions, either high school or university. Individual character is formed from a young age influenced by genetic and environment. Intentionally, character formation process will affect the way an individual sees himself and the environment, reflected in his/her behavior every day. College or University is a formal institution that assigned by the state to organize education and develop science, knowledge, technology, and arts.

It is recognized that character education is significantly required to be applied in university. Since the university is the place where students seeking knowledge in the complex. As an agent of change, university students should be equipped with values based on nationality pillars. In addition, as middle class, university students have a great responsibility to control changing progress acceleration. Control to the changing will be pragmatic when idealism and independence of university student do not base on value order. Therefore, comprehensive discussion regarding the implementation of character education in Syiah Kuala University based on local value is needed. 


\subsection{Problem Formulation}

According to the background illustrated above, five problems formulation are arranged as follow:

1. What kinds of values are actualized in strengthening students' character of Syiah Kuala University?

2. How shall actualization strategy of local wisdom values in strengthening student's character in Syiah Kuala University?

3. What are the challenges and opportunities of actualizing local wisdom values in strengthening student's character in Syiah Kuala University?

\subsection{Research Objective} follow:

Based on the problematic formula mentioned above, the objective of this research will be as

1. Describe in details actualized values in strengthening student's character at Syiah Kuala University.

2. Illustrate the strategy to actualize local wisdom values in strengthening student's character at Syiah Kuala University.

\subsection{Research Significance}

In general, the research significance will be useful to scientific literature development which directly related to the theory of development value. However, specifically, the research significance is described as follows:

1. As the main guideline for stakeholders in the process of strengthening students ' characters at the level of Syiah Kuala University.

2. In addition to Syiah Kuala University, the research significance can also be made as an initial guideline to other universities, both public and private universities in their support to strengthen the character of a university student.

\subsection{Theoretical Basis}

Generally, everyone would agree that character formation process as something critical. Character education is an attempt of transferring value in a process and at every level of education. In this matter, according to Elkind \& Sweet [3], character education is defined as follows:

"Character education is the deliberate effort to help people understand, care about, and act upon core ethical values. When we think about the kind of character we want for our children, it is clear that we want them to be able to judge what is right, care deeply about what is right, and then do what they believe to be right, even in the face of pressure from without and temptation from within".

Furthermore, character education is everything implemented by stakeholders, who are able to influence learner's character into positive change. The teacher helps in building learner's behavior, includes teacher's manners, the way of talking or delivering material, how teacher tolerate, and other related things. In this subject, according to Ramli [4], character education has the same definition and essence of moral education. The purpose is to create an individual with 
a good personality, good community, and a good citizen. Therefore, the nature of character education in the context of education in Indonesia is derived from its cultural educational value to build the personality of the young generation [5].

Character education is initiated from human basic character, deriving from universal values of moral (absolute), deriving from religion which is referred to as the golden rule. According to psychologists, some basic character values are: love to God and His creation (nature with its contents), responsibility, honest, respectful and polite, affectionate, caring and cooperation, confidence, creative, hard worker and perseverance, justice and good governance, good and humility, tolerance, love of peace, love and unity. Other opinion says that basic human character consists of: trustworthy, care and respect, honesty, responsibility; citizenship, sincerity, courage, diligence, discipline, visionary, fair, and have integrity. Implementation of character education in university should be based on basic character values, which are then in the next step developed into more or higher values in line with the requirements, conditions, and the environment of the campus.

Education specialist generally agreed on the substance of character education improvement on formal education corridor [6].

However, different opinions among them come up in terms of approach. In relation to approaching or method, some specialist suggests in the using of moral education approach that grown in Western countries, such as the cognitive moral development approach, analysis value approach, and clarification value approach. Others suggest in the using of traditional approach by setting in social values within learners [7].

According to grand design developed by Kemendiknas (2010)[8] psychologically and socioculturally, individual character formation is a function of entire potential human beings of the individual in the context of social and cultural interaction in lifetime progress. Configuration characters within the context of the totality of psychological and socio-cultural process can be grouped into: (a) Spiritual and emotional development; (b) Intellectual Development; (c) Physical and Kinesthetic Development), and (d) Affective and Creativity Development).

Specialists have suggested various theories concern on moral education. In this subject, according to Hersh, Miller, \& Fielding [9] among various developed theories, there are six theories which commonly used: rational development approach, consideration approach, clarification value approach, cognitive moral development approach, and social behavior approach [6]. In contrast to this classification, [10] classifies various theories into three: cognitive approach, affective approach, and behavioral approach. The classification is based on three elements of morality, which became the object of Psychological study: behavior, cognition, and affection [6].

Character education as a curricular program has been implemented in some countries. Research by Halstead \& Taylor [11] described how learning and teaching values as an approach in forming individual character has been developed in universities in the United Kingdom. According to Halstead \& Taylor [11], prominent roles of campus on character formation are based on the following values: "to build on and supplement the values children have already begun to develop by offering further exposure to a range of values that are current in society (such as equal opportunities and respect for diversity); and to help children to reflect on, make sense of and apply their own developing values".

Thus, it can be defined that character education is designed and implemented systems to help learners understand human behavior values related to God, human itself, among human beings, environment, and nationality that is embodied in mind, attitude, feeling, word, and deed based on religious norms, laws, manners, culture, and customs [12]. 


\section{Phases on Character Development}

The implementation of character education is a necessity because the goal of character education basically encourages generation with good character (insan kamil). A good character in somebody grows and develops to encourage him/her to have the ability to live in truth and life purpose. Thus, it will encourage Indonesian new young with true character.

It should be recognized that character development is not something easy, or as simple as turning hand palm. However, character development requires intensity based on high consistency attitude from all stakeholders. That is because individual character development has particular phases. Thus, pattern approach adjustment in learner's character development is significantly based on referred phases.

The following two references from a specialist are important in relation to moral development phases. First, Jean Peaget [13], said that moral development takes place in two phases. The first phase is called moral realism the second phase is called autonomous morality. In the first phase, children judge an action as right or wrong according to its consequence, rather than the motivation behind them. Children morality automatically follows the rules without thinking or judging, and they tend to assume that adults have power. The main here, according to Piaget, that children assess right and wrong based on punishment, rather than its moral values. In the second phase, cognitive development in children had been created and they can consider all possibility to solve a particular problem. At this phase, children have the ability to see problems from a different point of view and may consider possible factors to solve the problems.

Second, Lawrence Kolhberg [13], which has the opinion that moral development at an individual person passes through three phases. Each phase consists of two sub-phases. Phases that defined by Kohlberg are divided into several levels.

1. Pre-conventional phase

Consists of two phases, orientation phases on children compliance and punishment by doing something to earn prizes, or without charge any punishment; relativistic hedonism phase, children are no longer depends on rules, but they start in to realize every relative incident and orienting more on satisfaction principles.

2. Conventional phase

Focus on social needs. Phases in conventional time consists of two phases: orientation regarding on good children, where children will perform action and others able to judge; phase on defending social norms and authority, where children aware of their obligation, implementing norms and defending norms existence, by means to live in harmony, social groups should accept and implement rules agreement.

3. Post-conventional phase

An individual internally looks moral judgment on proper principles. There are two phases, orientation on agreement between an individual with social environment, reciprocal relationship between individual and social environment presents when a person carrying out his duties in accordance with social demands norms, he hopes to get protection from community; have universal principles, subjective ethical norms and personal norms are presents which means that subjective elements in the relationship between one person to society are presents to judge if an action is good or not good, with moral or not.

Furthermore, according to Adler [14], there are two main impulses in human that influence his behavior, egoism encouragement and social encouragement. Egoism encouragement appears in individual ego; while social encouragement appears ina cooperative, social relation, interpersonal relations, and group relation, etc. In other words, social encouragement means to conform to society as an environment and help them to gain perfect purposes [6]. The same 
opinion is expressed by Edwards Lee Thorndike [13], an adherent of psychological behavior. Adler uses the term "social encouragement", but Thorndike expresses "learn" in describing the behavioral background of someone. Which means that it associates between events in someone's environment, he calls it "stimulus" which is the response given to the stimulus.

According to some thoughts above, the character is developed in the stages of knowledge, implementation, and habits. The character is not only limited to knowledge. A person who has knowledge of goodness is not absolutely capable to act in accordance with his knowledge if $\mathrm{s} / \mathrm{he}$ is not used to it. Character is also reaching out emotion and habits. Thus, it is required three components of good character, moral knowing (knowledge about moral), moral feeling (emotional reinforcement) about moral and moral action. Those are necessary to have students who involved in education system understand, feel, comprehend, practice moral values.

Seeking further, dimensions include in moral knowing that will load in cognitive domain is moral awareness, knowledge regarding moral values (knowing moral values), perspective point of view (perspective taking), logic of moral (moral reasoning), courage to behave (decision making), and self introduction (self knowledge). The moral feeling is about strengthening the emotional aspect of the learner into a characterized human. This reinforcement is linking to attitudes perceived by learners, i.e. awareness of identity (conscience), confidence (self-esteem), the sensitivity of suffers (empathy), love the truth (loving the good), restraint (self-control), humility (humility). Moral action is the outcome of Performa resulted in two other character's component. Understanding what encourage someone in performing goodness (act morally), should be observed in the other three characters, i.e competence, will, and habit.

\section{Local wisdom value}

Local wisdom concept in the dictionary consists of two words: wisdom and local. However, in general, local wisdom implicitly defined as local ideas with full of wisdom, discernment, good-value, embedded and followed by member community. In term of anthropology is known as a local genius.

Gobyah [15] said that local wisdom (local genius) is a truth that has been cultured in a local area. Local wisdom is a combination of sacred values and various existing values. Local wisdom is created an advance local culture in the community or geographically. Local wisdom is a product of a past culture that should be constantly stood as a way of life. It is local value but somehow values in it believed as universal. Local wisdom is also a source of knowledge generated dynamically and develops or carried on by certain populations integrated with their understanding of surrounding natural and culture.

Local wisdom is fundamental for policy maker in local level regarding health, agriculture, education, natural resource management, and rural community activities. Local wisdom sometimes is also local culture wisdom. It is local knowledge unified with belief systems, norms, a culture which expressed in tradition and myth, embraced in a long time period.

\section{Methodology}

This study uses a descriptive qualitative approach to describe the process of strengthening student character through local wisdom values. The selection of informants is done in a structured and systematic manner, besides that, it is also done by means of purposive sampling to get answers to controls from informants at other levels besides students. Informant or Subject in the study was 45 persons consist of four elements. There were 10 main persons who stand as leaders in university, and other 10 persons stand as the element faculty leaders. Next 10 persons 
stand as organization leaders from university students, and the last subject, 15 persons stand as a lecturer with character education. The process of collecting data in this study was gained indepth interview with the selected subjects. Since data in this study is qualitative, so data analysis is also performed in descriptive in accordance to the cycle that suggested by Miles \& Huberman [16] that "data analysis consists of three activities implemented together, those are data collection, data reduction, data presentation, research conclusion". The cycle of whole data analysis by Miles and Huberman.

\section{Results and Discussion}

After generating an interview with selected respondent regarding on local wisdom actualization value in order to strengthen student's local character of Syiah Kuala University, following discussion related to research would be:

\subsection{Actualized Local Wisdom Values in strengthening student's character at Syiah Kuala University}

Local wisdom values that live and develop in the community have generally agreed as values that remarkable to be actualized in the process of strengthening learner's character. The result of the research also revealed that local wisdom values end down to three main sources. First, religion value, enlighten people of Indonesia in general, and Acehnese as Moslem community. Therefore, Islamic values have been unified into Acehnese in particular. Those values internalized as the main value for character education process at Syiah Kuala University in Banda Aceh. Islamic values are faith, honest, reliable, smart, and humanist values as basic human rights context. If necessary, training on Syaria Islam should be undertaken in the early admission of new students, and each of them must follow the training as well as the training of national internalization of 'orde lama' and 'orde baru' through P4 training.

Second, local wisdom values in Acehnese are influences by nationalism values in line with Pancasila, 1945 Constitution, and Bhinneka Tunggal Ika and The Unitary State of Republic Indonesia. The nationalism values are unity, mutual respect/tolerance, love of homeland, loyalty and other pillars living as a nation and country. The respondent argued that we live in a plural country instead of homogeneous. We live diverse ethnic, language, race, culture, and customs, and nationalism stand as life adhesive among multiculturalism in Indonesia. However, Indonesia can stand in unity to develop Indonesia into a big country.

Third, other local wisdom values are affected by former customs and culture of the community. According to respondents, local values currently ignored in the education process. Meanwhile, Aceh has been given special autonomy and it is possible to develop students character based on Acehnese values. Some local wisdom values based on Acehnese customs and culture are: like helping each other, respecting elder people, high care, humble, not greedy, simple life, loyal to the family and brave. Acehnese in history is known as brave and tough. Even Dutch assume that Acehnese is modern. Today, courage in Acehnese generation had begun to fade if compared to the former. Acehnese was ready to sacrifice their treasure and their life to defend truth principles. So, Acehnese values should return and internalize in strengthening the process of student's character in Syiah Kuala University, and even in all levels of education as the process of learner's character formation. 


\subsection{Actualization strategy of local wisdom values to strengthen student's character in Syiah Kuala University}

In relation to the implementation of actualization strategy, building character education for students of Syiah Kuala University is implemented by curricular, co-curricular and extracurricular. Curricular activities are definitely related to learning activities guided by the curriculum, in this subject is Basic Social and Cultural Sciences (ISBD), Islamic Science, Nationality Education, and Pancasila Education. In addition to the subjects' religion, ISBD, and $\mathrm{PKN}$, another local material is added. The local material is not only, but discussing local wisdom in Aceh, initiated from historical view up to Acehnese local wisdom an how it is implemented in farming, guarding forest, trading, resolving disputes and resolving large scale of conflicts.

Besides the implementation of learning value by specific local subject, ISBD, religion, PKN, and Pancasila, the other way is inserting values to all subjects, or in another word formally unified into each faculty. Spiritual refreshment at the beginning of the learning process can be the method before getting into core subject. This should be performed in every learning process every time. Then, in relation to character development values through curricular, the most important is performing all course by obligating proper Course Events Unit. In some cases, many lecturers fail to remember teaching planning, more or less standard of content, and competency standards. Therefore, by well-prepared curriculum and tutorial, the result would be remarkable. Student Center Learning (SCL) should not be forgotten in the process of character education, students are getting more active than lecturer, they studying material and doing presentation to have a space for discussion, here we can develop values, patient, respecting opinions, politeness, skills to argue, the way of good communication is less seen in our current students.

In addition to curricular, actualizing local wisdom value can also be performed through extracurricular. The strategy: first, creating a group study. This group study is required in any program or faculty. In this group study, the interaction will be intensively present between each other, they will learn awareness to each other, and they will learn how to appreciate others, compete fairly. Second, by inviting students to participate in a seminar and general lecture. Third, provide regular training on each semester to all students. The training means leadership training, entrepreneurial training and etc. As for an extra-curricular activity, those training mainly required and expanded in university. Actually, extra-curricular activities can also very effective as a medium of internalization for local wisdom values. Research findings have also proved that standard operational procedure (SOP) is important in the implementation of extracurricular activities.

Then, actualizing strategy for local wisdom through co-curricular activities should be carried out, the strategy is: first: by assessment (evaluation), lecturer provides a special award for students to get involved in co-curricular activities, awarding them 10 percent of student total grade. This system has never applied so far. Thus, students will often engage in co-curricular activities, and they will learn more in many aspects related to their character formation, discipline, cooperation, and honesty in the team. Second, expanding dedication activities, this can be performed during vacation. Students will learn more about empathy and sympathy as well as responsibility to look down at phenomena in the field. Therefore, those three activities: curricular, extracurricular, and co-curricular are the strategy to actualize local wisdom values in Syiah Kuala University in order to strengthen student's character.

There are at least three models of approach or method that is applied in the process of actualizing local wisdom value: (a) integrative model, (b) complement model, and (c) discrete model (separate). First, integrative model, character implementation is attached and integrated 
into curricular programs, curriculum, and existing courses or even the learning the process. Curricular programs or courses should contain character values. This model requires the keenness and high ability from the teacher. S/he is required to be creative, full of initiative, and fully loaded with ideas. Teachers must be smart and clever to plan and outlining the curriculum, manage to learn, and developing awards. Despicable is a plus for this model since it is not charged expensive fare and no need to add lecturer.

Second, complement model or character implementation, which is inserted into the curricular educational program and existing curriculum structure rather than courses. The implementation of this model can be performed by adding characters subject as local content in curriculum structure. This Model requires an extra specific time, additional lecturers and requires expensive fares. In addition, this model can burden students and lecturers since it needs higher financial and implicate the institution. However, this model can be optimally and intensively used to build a student's character. Third, the discrete model, separated implementation character, divided and released from curricular programs or courses. Its implementation could be packaged and served specifically to the student. Its presentation could be related to the curricular program or could be extracurricular. The model requires excellent preparation, expensive fare, and school preparedness. This model also requires good planning to prevent miss-application; however, this model still can be used to create learner's character comprehensively and relieved.

From all these three models, the complement model is generally used to actualize local wisdom values at Syiah Kuala University, which allows local subject course in addition to particular courses such as religious education, ISBD, and PKN. It is possible due to special autonomy that allows adding local course content as far as not interfering national curriculum system. Then, a special institution with a default structure is required: there should be a Chairman who serves as coordinator with a number of staff, not so many, the most important is the Expert Council which consist of representative from faculties, the Dean from faculties, and one person that is selected from each faculty in accordance to the Track record. The Institution should be directly under the rector.

\section{Conclusion}

Following on field data collection and the discussion, it can be summarized that:

1. There are three sources of Acehnese local wisdom that can be formulated as fundamental to strengthen student's character at Syiah Kuala University.

2. Implementation strategy of character education is performed through curricular activities: religious subject, ISBD, PKN, and local content course which able to be included in any new course program. While the implementation of character education through extracurricular activities and co-curricular can also be carried out with full responsibility by a Standard Operational Procedure (SOP).

According to this research, suggestions have been formulated as follows:

1. University needs to insert a character education program in the annual budget. The financial stimulus is required in terms of character education to support and have optimal character education program.

2. University and faculty, as well as study program, should commit clearly to implement character education program at Syiah Kuala University.

Together, the University and technical implementation unit should monitor and evaluate the implementation process of character education 


\section{REFERENCES}

[1] A. Hasyim, Kebudayaan aceh dalam dilema konflik dan konsensus. Banda Aceh: Bandar Publishing, 2009.

[2] Undang-Undang Republik Indonesia Nomor 20 Tahun 2003, Sistem pendidikan nasional. Republik Indonesia, 2003.

[3] D. H. Elkind and F. Sweet, "How to do character education," Artik. yang diterbitkan pada bulan Sept. 2004., 2004.

[4] T. Ramli, Pendidikan karakter. Bandung: Angkasa, 2003.

[5] T. Lickona, Mendidik untuk membentuk karakter. Jakarta: Bumi Aksara, 2012.

[6] S. Bahrein, Perubahan sosio-kultural dan sikap proses modernisasi (suatu studi atas masyarakat aceh dalam tradisi). Banda Aceh: BeunaCitra, 2009.

[7] D. K. Windrati, "Pendidikan nilai sebagai suatu strategi dalam pembentukan kepribadian siswa," J. Form., vol. 1, no. 1, pp. 40-47, 2013.

[8] Kemendiknas, "Pembinaan pendidikan karakter di sekolah menengah pertama," Jakarta, 2010.

[9] R. . Hersh, J. . Miller, and G. . Fielding, Model of moral education: an appraisal. New York: Longman, Inc, 1980.

[10] J. L. Elias, Moral education: secular and religious. Florida: Robert E. Krieger Publishing Co., Inc., 1989.

[11] J. M. Halstead and M. J. Taylor, "Learning and teaching about values: A review of recent research," Cambridge J. Educ., vol. 30, no. 2, pp. 169-202, 2000.

[12] U. S. W. Putra, "Paradigma pendidikan kewaganegeraan," J. Civ., vol. 2, 2009.

[13] K. Berterns, Etika. Jakarta: Gramedia, 1993.

[14] A. Adler, The origin of the neurotic disposition. New York: Basic Books, Inc, 1956.

[15] Gobyah, Pengenalan keraifan lokal indonesia. Jakarta: Rineka Cipta, 2003.

[16] M. B. Miles and A. Huberman, Analisis data kualitatif buku sumber tentang metodemetode baru. Jakarta: Universitas Indonesia, 2007. 